\title{
PSICOLOGIA DA CRIAÇÃO
}

\author{
MárIo de Andrade
}

("Mundo Musical", Folha da Manhã, 11-11-1943.)

\section{C}

omo eu contei da última vez, as minhas preocupações dos problemas do teatro musical, tinham me levado a concluir que a desmoralização normal da ópera não derivava de forma nenhuma de defeitos artísticos ou mais particularmente estéticos, mas de deformações vindas de fora para dentro, interesses dominadores de classe, interesses traiçoeiros de artistas. Não eram defeitos de origem, próprios do teatro cantado, mas vícios adquiridos em caminho. E por isso, não havia necessidade nenhuma de "reformar" a ópera mais uma vez, lhe dar uma concepção estética nova, mas apenas lhe observar as origens, voltar às fontes e aos exemplos populares e tradicionais em que o teatro cantado preservava mais genericamente as sociedades, visando-lhes sempre as instituições básicas. Não era a ópera que tinha de ser reformada, a escolha dos assuntos é que carecia ser mais humanizada, por assim dizer. O teatro sem amor, o grande teatro sem amor de todas as verdadeiras épocas do teatro social, porque o amor está na base das instituições familiares, não porém exatamente das da sociedade. Só nesse ponto das minhas cogitações me veio de supetão aquela primeira ideia criadora: não seria possível tentar uma ópera de interesse mais social tendo como base de assunto o café?...

Aqui eu seria certamente imperfeito se quisesse dar uma concatenação lógica aos elementos de ordem estética e de ordem artística que logo se impuseram a mim. Não eram muitos, ou pelo menos não foram muitos os que sobraram daquele turbilhão convulsionante de imagens, de ideias, de juízos que me arrebatavam, numa volúpia sublime. A música, feia ou bonita nem me lembro, me incomodava, deixei o ato em meio, fui andar na rua, ver se conseguia me organizar um bocado. Na verdade, desde início, dois princípios, um de ordem estética, outro de ordem artística, se impuseram e fixaram em mim, derivados dos dois elementos da primeira ideia criadora: $1^{\circ}$ - ópera de interesse coletivo; $2^{\circ}$ - o "Café". Ordem que estabeleço agora apenas para clareza de exposição.

A noção "ópera coletiva" tivera uma resposta imediata, que será talvez a originalidade mais atrevida da minha criação. Não se tratava apenas de fazer um libreto que pudesse interessar coletivamente uma sociedade, mas que tivesse uma forma, uma solução técnica derivada do conceito mesmo de coletividade. Uma ópera coral, concluí. Um melodrama que em vez de lidar com indivíduos, lidasse com massas; em vez de solistas virtuosísticos que sempre foram o elemento principal 
de desmoralização artística, convertidos a semideuses de culto na Grécia, como a semideuses de ouro em nossos dias: em vez de solistas, coros: em vez de personagens solistas, personagens corais. Enfim uma ópera inteira exclusivamente coral. Está claro que a audácia de semelhante solução estética, a complexidade dos seus problemas técnicos me aturdiam, o perigo da monotonia me assustava, mas a decisão estava bem fixada em mim. Não era aquele o instante de resolver problemas.

Quanto à solução artística (eu distingo aqui como em muitos meus escritos destes últimos anos, "estético" como referente exclusivamente aos elementos de beleza da obra de arte, e "artístico" como referência mais direta e geral à arte como instrumento de comunicação entre os homens) quanto à solução artística do assunto a própria história mais recente e dramática do café se impunha como convite. A crise de 1929, a revolução de 30. É óbvio que desde logo afastei repugnado qualquer ideia de cantar historicamente uma revolução determinada. Sem que pusesse consciência nítida nisso, o que me determinava mais profundamente era aquele eterno e universal princípio místico de "morte e ressurreição" do deus da natureza, do sustento tribal, que está na base duma infinidade de tradições e costumes etnográficos e folclóricos, atingindo mesmo certas formas da sociedade civilizada. E talvez seja a própria inspiração primeira de todo o teatro cantado, na Grécia, na Ásia, na Idade Média e fundamenta as nossas danças-dramáticas de origem não erudita, os Congos, o Bumba-meu-Boi, os cordões de bichos e já eruditamente, os pastoris religiosos. Princípio que eu disse "místico" porque este foi $\mathrm{o}$ aspecto em que ele se universalizou nas sociedades primitivas e adquiriu feição didática (teatral...) mas que está na base das próprias formas econômicas e institucionais das sociedades. Mesmo nos tempos policultores mais acertados de agora, e apesar de institutos, de armazéns reguladores e o diabo, se pode dizer que a oscilação da economia paulista determina-se pela morte e ressurreição ânua do café. E com efeito, no meu libreto futuro, eu poria várias frases na voz coral popular que implicassem a noção inconsciente e transcendente de morte e ressurreição. Mas isto já é exegese. O importante, o que se impunha a mim naquele instante, era a tradução de toda essa mística complexa num princípio mais claro e apreensível a todos: desde que depereceu o produto que faz a riqueza normal duma terra, vem a insatisfação pública que acaba se revoltando e mudando o regime.

Isso bastou para que um primeiro enredo se impusesse imediatamente. Aí, com muita lógica conclusiva, o que surgiu primeiro, foi o final do último ato: uma cena triunfal de revolução vitoriosa. O efeito fácil duma apoteose apenas um segundo me preocupou esteticamente. É preciso não confundir o fácil com o banal, como fazem os pedantes, e eu queria elementos fáceis, que pudessem servir com imediateza ao público. As outras cenas seriam enchidas por choques de classes, provocados pela depressão econômica, choques rurais e urbanos, uma cena de porto, uma cena de cafezal. Preciso aproveitar a bonita composição plástica dum armazém abarrotado de pilhas de sacas de café... Mas está tudo muito soturno, muito trágico e devo desfatigar o público de vez em quando... E se eu fizesse uma cena pândega, caçoando com as nossas câmaras de deputados, ótimo!

Surgiu a ideia do primeiro ato, que não tem nada que ver com câmara de deputados, mas vinha deduzida da preocupação de divertir um bocado o meu público 
e não acumular elementos dramáticos. A bem dizer a inspiração, o instante sublime da criação se acabara. Porque, de passagem, eu sustento a teoria velha da "inspiração", embora os avanções da psicologia que permitam analisá-la "até certo ponto", e até certo ponto muito íntimo lhe penetrar o mecanismo. É evidente que se eu não estivesse perseguido pelo remorso daqueles dias de desmoralidade em que me rira duns infelizes, não me tivesse preocupado com a regeneração do teatro musical, não estivesse por aqueles tempos escrevendo um romance que girava em torno do café; é evidentíssimo que se por aqueles anos eu não estivesse estraçalhado por preocupações a respeito de ideologias políticas, eu não teria aquela "inspiração". Nada impede que fosse uma inspiração instantânea, em pleno teatro de hórrida ópera, e fosse sublime. Porque este ainda é outro ponto em que discordo dos que consideram a criação um "parto dolorosíssimo". Nem doloroso nem parto. Mas não é lugar aqui pra distinguir entre criação e todos os demais processos de "enchimento" e polimento, honestíssimos e necessários, que completam a obra de arte. Estes é que são de fato muito penosos. E era o que já estava sucedendo comigo.

Como eu disse, o momento inspirado da criação se acabara, meu espírito se fatigara no turbilhão vivido um quarto de hora. E agora eu já estava compondo. A preocupação de não fatigar muito o público em cenas dolorosas me trouxera aquele primeiro ato. Seria o cafezal, uma cena graciosa de colheita, as crianças trazendo o almoço dos colonos, rodas tradicionais infantis, brinquedos de rapazes e garotas se namorando. E apenas uma leve melancolia pra terminar o ato: a retomada da colheita após o almoço com o coral a quatro vozes de velhos e casados, denunciando a falta de pagamento e as primeiras dificuldades e angústias.

O segundo ato sim, seria todo dramático, uma primeira cena no armazém, com os estivadores sem trabalho, o porto não exportava mais café. E uma segunda cena, a discussão na sede da fazenda, entre as massas dos colonos e o fazendeiro, preparando o estouro próximo da revolução. Principiava me entusiasmando outra vez. E se logo repudiava a imagem sonora do fazendeiro (por ser solista) e o substituía por uma Comp. Cafeeira S. A., um grupo de donos entregando por dívida a fazenda aos comissários, entre a grita dos colonos exasperados, ao mesmo tempo me trabalhava a preocupação estética de se tornar por demais fatigante um melodrama inteirinho coral. E me surgiu nos olhos e me solicitou o ouvido uma mulher, engraçado, uma mulher que eu enxergava se erguendo e principiando a clamar, era a Mãe - a receptora de todos os sofrimentos. Um solo vasto, a Mãe contando as desgraças vivas, que eu enxergava muito bem na sua mancha colorida, dramática e solitária, toda cercada de gente, dos lados, por baixo, por cima, gente gesticulando. Aquela visão me fez voltar à imagem da câmara dos deputados, em anfiteatro, e a Mãe (pobrezas da lógica...) era uma deputada trabalhista que tomava a defesa do povo contra todas as bancadas com as galerias no fundo aplaudindo num coral de bagunça formidável. A coisa viera bem graduada, eu imaginava: esta primeira cena do terceiro ato era mais forte, mais preparatória que a discussão na fazenda. E a cena da revolução coroava logicamente a peça, com o seu hino de apoteose triunfal.

Essa foi a primeira concepção do "melodrama" "Café". Já estava me repugnando dar ao meu libreto o subtítulo "ópera" tão desnorteador, e o substituía por "melo- 
drama"... Mas chegado a esse ponto, não pude mais continuar em ideias nem juízos. Tudo fora principalmente imagem, me era impossível continuar criando ou enchendo enredo dramático, eu estava todo convertido a imagens. Somente isso, a preocupação derivada das minhas ideias sobre teatro, que tem de ser, preliminarmente e sobretudo, espetáculo, uma coreografia plástica, despreocupada de realismo, tendendo à formação de visões plásticas. O espetáculo é uma seriação de quadros vivos, em que cada quadro-vivo, corresponde a um momento dramático que se quer salientar, se movimenta em seguida e vai formar novo quadro vivo. $\mathrm{E}$ cada quadro-vivo, correspondente a cada momento importante de significado do enredo, tem todas as exigências de um quadro de pintura: exige composição e equilíbrio (este especialmente dinâmico no seu ritmo, pois que o quadro é vivo e vai se movimentar para a formação de outro novo) de cores, de volumes, de claro-escuro. Só ecoava em mim agora o sentimento plástico. E com efeito, a primeira e única coisa que "escrevi", chegado em casa, foram os desenhos dos cenários, ou melhor, dos cinco momentos principais das cinco cenas do melodrama. $\mathrm{O}$ resto ficava pro dia seguinte.

[Texto reproduzido de: Jorge Coli, Música final: Mário de Andrade e sua coluna jornalística Mundo Musical, Campinas, Editora da Unicamp, 1998, p. 104-107. Foi feita a atualização ortográfica.] 